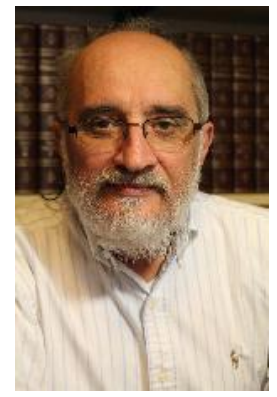

\title{
MACEDONIAN JOURNAL OF CHEMISTRY AND CHEMICAL ENGINEERING: OPEN JOURNAL SYSTEMS - EDITOR'S PERSPECTIVE
}

\section{Zoran Zdravkovski}

Institute of Chemistry, Faculty of Natural Sciences and Mathematics, Ss. Cyril \& Methodius University, Skopje, R. Macedonia

Corresponding Author: Prof. Zoran Zdravkovski, Editor-in-Chief, Macedonian Journal of Chemistry and Chemical Engineering; Institute of Chemistry, Faculty of Natural Sciences and Mathematics, Ss. Cyril \& Methodius University, Skopje, Macedonia; Phone: +389 (0)2 32499 26; E-mail: zoran@ukim.edu.mk

\begin{abstract}
The development and availability of personal computers and software as well as printing techniques in the last twenty years have made a profound change in the publication of scientific journals. Additionally, the Internet in the last decade has revolutionized the publication process to the point of changing the basic paradigm of printed journals. The Macedonian Journal of Chemistry and Chemical Engineering in its 40-year history has adopted and adapted to all these transformations. In order to keep up with the inevitable changes, as editor-in-chief I felt my responsibility was to introduce an electronic editorial managing of the journal. The choice was between commercial and open source platforms, and because of the limited funding of the journal we chose the latter. We decided on Open Journal Systems, which provided online submission and management of all content, had flexible configuration \pm requirements, sections, review process, etc., had options for comprehensive indexing, offered various reading tools, had email notification and commenting ability for readers, had an option for thesis abstracts and was installed locally. However, since there is limited support it requires a moderate computer knowledge/skills and effort in order to set up. Overall, it is an excellent editorial platform and a convenient solution for journals with a low budget or journals that do not want to spend their resources on commercial platforms or simply support the idea of open source software.
\end{abstract}

Key words: open source software, Open Journal Systems; electronic editorial managing

\section{Short history of the Journal}

The first issue of the Macedonian Journal of Chemistry and Chemical Engineering (MJCCE) was published in 1974, exactly 40 years ago. Its title initially was Bulletin of the Chemists and Technologists of Macedonia ( $\Omega$ cник н хемич рийе и технолозите н кедониј ) and the first Editor-in-chief was Prof. Dr. \%RMD âRSWOMRY The idea behind this journal was to join efforts of the human potentials and expertise and other resources from the Institute of Chemistry (IC) at the Faculty of Natural Sciences and Mathematics with the Faculty of Technology and Metallurgy (FTM), in order to publish a journal with higher standards. The sacrifice \pm both institutions gave up and discontinued their corresponding faculty publications (Anпиаire \pm одишник) and published a joint journal within the guidance of the Society of Chemists and Technologists of Macedonia (SCTM).

The journal was modelled after Croatica Chemica Acta, published by the Croatian Chemical Society and was part of the edition Documenta chemica Yugoslavica. Other chemical society journals also belonged to this edition: Bulletin of the Chemical Society of Belgrade

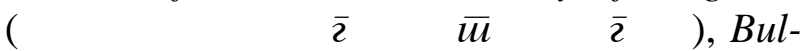


letin of the Slovenian Chemical Society (Vestnik Slovesnkega kemijskog društva) and Bulletin of the Chemists and Technologists of Bosnia and Herzegovina (Glasnik hemičara i thenologa Bosne i Hercegovine). In other words, the ambitions were set high and strict editorial practices were established from the beginning, the most important being that every manuscript had to be peer reviewed. Technically, as was the case at the time, it was very demanding since the typesetting of scientific manuscripts was very laborious and required very careful corrections and editing. As a matter of fact this generation has gone through profound changes in the preparation of manuscripts, from old fashioned typewriters to electric ones, then IBM selectric with various typeball font elements, daisy wheel printing, and then to personal computers with a number of text editing softwares, as well as software for drawing and modelling chemical structures etc.

Further major editorial changes were made in 1990 when it was decided that all manuscripts had to be reviewed by two peer reviewers, one of them from outside Macedonia. Furthermore, all scientific papers had to be written in English only with a Macedonian abstract; previously they could be written in German, French, Russian, Serbo-Croatian or Macedonian. Another important decision was not to publish proceedings from the SCTM congresses. At the beginning, most of these decisions were criticized by some SCTM members but proved to be farsighted in improving the overall quality and impact of the journal.

In 2007 the title of the journal was changed to the present one and steps were taken to apply for an impact factor (Figure 1). Most of the requirements were met from the beginning of this process/procedure, but the publishing schedule had to be strictly obeyed and it was decided to publish two issues per year, one issue in June and another in December. The same year MJCCE was included in Science Citation Index Expanded and three years later in Journal Citation Report/Science Edition, i.e. in 2010 the first impact factor was obtained (IF = 0.2 ). The IF values have changed as follows during the past five years: 2011 (2009-2010) 0.459; 2012 (2010-2011) - 1.079; 2013 (20112012) - 0.821; 2014 (2012-2013) - 0.310; 2014 - fifthe year (2009-2013) - 0.622.
In the past 40 years the following have been appointed Editors-in-chief of the journal: Bojan Šoptrajanov (1974-1989) - IC; Miodrag Brajović (one issue in 1984) - FTM; Svetomir Hadži Jordanov (1989-1993) - FTM; Gligor Jovanovski (1993-1997) - IC; Maja Cvetkovska (1997-2001) - FTM; Trajče Stafilov (20012005) - IC; Eleonora Winkelhausen (2005-2009) - FTM; Zoran Zdravkovski (2009-) - IC.

\section{Installing the Open Journal System}

One of the first considerations as a new Editor-in-Chief in 2009 was to modernize the web presence of MJCCE along the lines of contemporary electronic publishing. A very basic web page had already been introduced in 2007, but the whole editorial process was still conducted by e-mail which was very cumbersome and inefficient. In order to achieve this goal the options were very limited, we could adapt ScholarOne Manuscripts which had many advantages such as excellent support, integration with Web of Science and EndNote, good security, digital archiving, plagiarism detection etc. As a matter of fact it had only one drawback: the high cost which we were unable to provide even for one year and with no steady budget, very difficult to sustain.

Once I became aware of the Public Knowledge Project [1] and their Open Journal System [2] I started reading about it and the more I read the more I was assured that it was our only solution to my vision of a journal fit for the electronic age. It provided installation locally and could be locally controlled, it had a flexible configuration - requirements, sections, review process, etc., had online submission and management of all content, had options for comprehensive indexing part of global system, offered various reading tools, had email notification and commenting ability for readers, had an option for thesis abstracts, etc. And above all it was open source, so it was free of charge. The weakness - most of the things had to be done by oneself with very limited support.

I decided to take on the challenge and a new PC was set up as a server and version 2.3.6.0 of OJS was initially installed in November 2011 on a Ubuntu 11 operating system [3] with the help of a system engineer. All further setup was done without any help, so at the same time I became web master and editor-in-chief. 


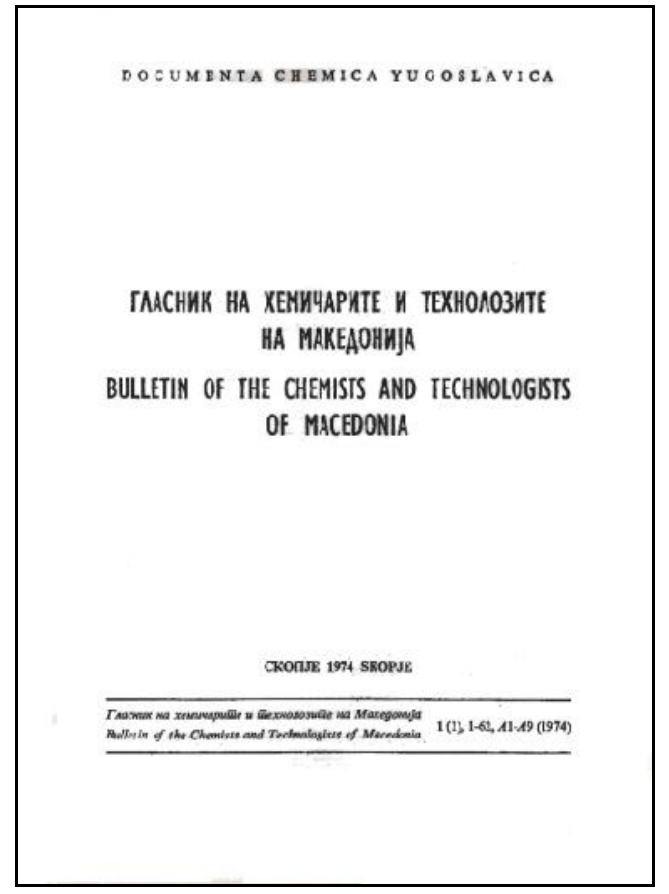

(a)

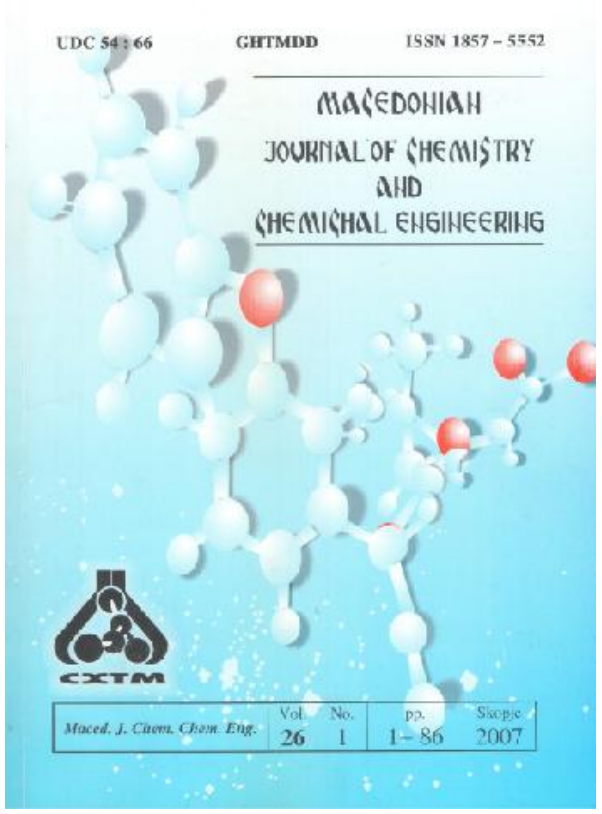

(c)

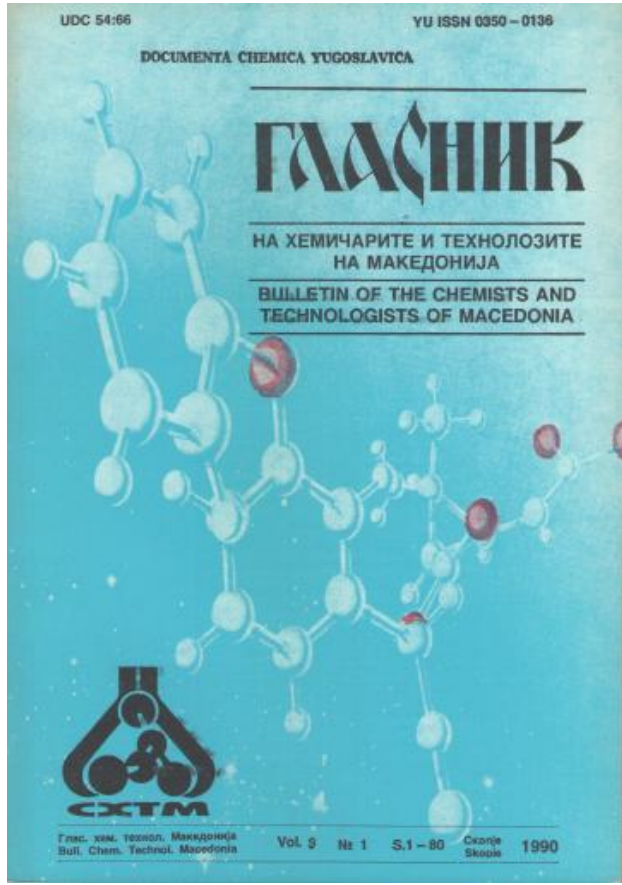

(b)

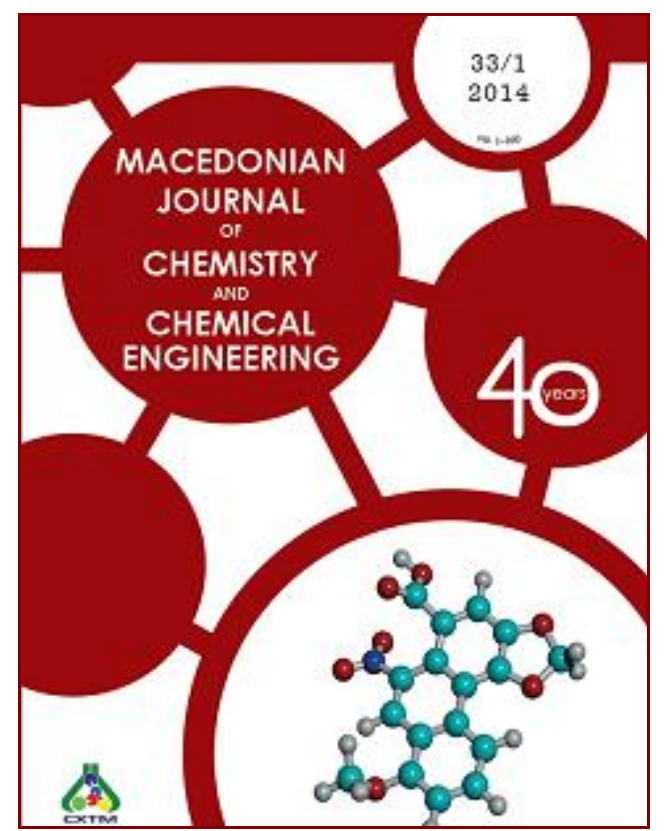

(d)

Figure 1 - Various covers of the journal a) first issue, b) new cover in 1990 c) new name and $\boldsymbol{d}$ ) the latest cover introduced this year

Setting up the journal proved to be fairly straightforward, mostly filling up various forms, editing template letters, etc. After installation and setting up the whole system, the testing period started among some of the members of the editorial board and colleagues who were computer savvy: testing various options for submitting an article, selecting section editors, selecting and sending letters to reviewers, filling up review forms, sending notices to authors, accepting or rejecting manuscripts. The first real but con- trolled submissions with the cooperation of the authors were made only six months later. The testing period lasted for the next several months until we had enough confidence and closed the old web page and turned fully to the OJS.

In October 2013 version 2.4.2.0 of OJS was installed on a Cent operating system (the free version of Red Hat Linux) [4] which was installed by the leading security IT experts in Macedonia and as a result we felt a little more relieved from hacker attacks. This was impor- 
tant since our old page was once attacked and the whole site was down for more than a month, which actually speeded up our decision to move to a new server with a Linux operating system and OJS (Figure 2).

Aside from the great advantages of the new editorial management system, there have been some problems. As expected, whenever there are problems with the network, the server is unavailable - but that is the fate of all internet services. This is maybe more pronounced in the case of our faculty network which needs a major overhaul.

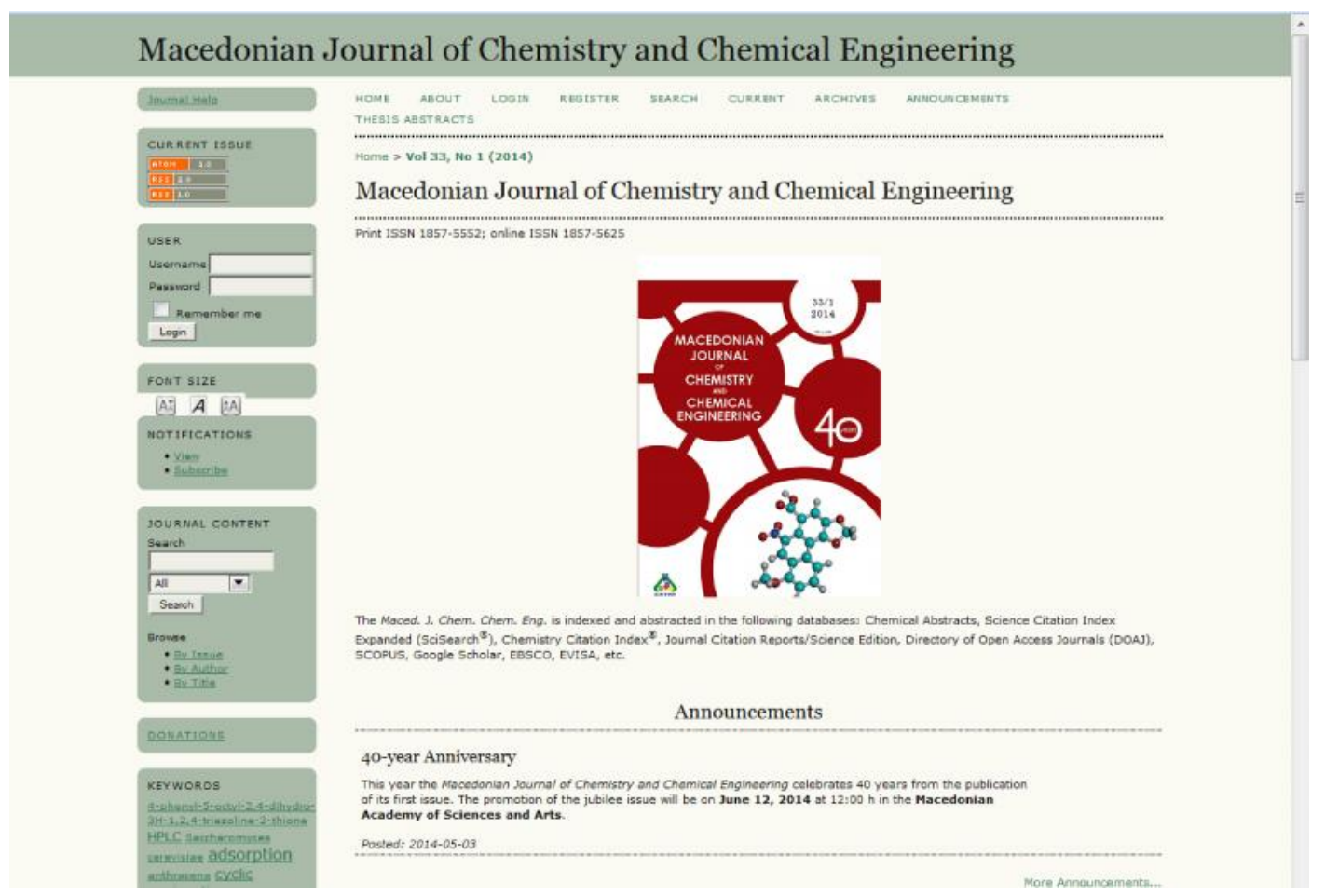

Figure 2 - Web page (www.mjcce.org.mk) of the Macedonian Journal of Chemistry and Chemical Engineering based on Open Journal Systems

A very frequent problem with authors is that they do not fill the metadata and are not aware that these are important not only for creating the content page of each issue but also for indexing services such as Scopus etc., which draw the names of the authors, titles, abstracts, keywords and references from them and not from the manuscript itself.

Some of the reviewers do have problems with the software, it would be probably more correct to say with computers in general, and although willing to do a review have an adverse attitude towards the whole platform. In such cases we send them the manuscript and reviewer's form by mail. We expect that with time and with younger generations of users such problems will disappear.

There is potential danger as with all digital archives that due to various reasons, including hackers, the electronic content can be damaged or totally lost. As a precaution a bac- kup is made daily and kept on a different computer. Fortunately, we have not needed to use the backups and since installing the OJS and the Linux operating system we have not had problems with suspicious activities.

\section{Conclusion}

Open Journal System is an excellent editorial platform and a convenient solution for journals with a low budget or journals that do not want to spend their resources on comercial platforms or simply support the idea of open source software. As an illustration of the last point, in 2013 over 5000 journals worldwide, a substantial number of which are in developed countries, have been using OJS editorial platform. It does need a moderate computer knowledge/skills and effort in order to set up. The additional benefits are that the editors are in full control of the site, its content and the required changes can be made without external dependence. 


\section{REFERENCES}

1. Public Knowledge Project. Open Journal Systems. Available at: https://pkp.sfu.ca/ojs/ Accessed: October 6, 2014.

2. Ubuntu. The leading OS for PC, tablet, phone and cloud. Available at: http://www.ubuntu.com/ Accessed: October 6, 2014.

3. CentOS Project. Cent Operating System. Available at: http://www.centos.org/ Accessed: October 6, 2014).

Р е 3 и м е

\section{ор н др вковски}

Институт за хемија, Природно-математички факултет, Универзитет „Св. Кирил и Методиј“, Скопје, Р. Македонија

Развојот и достапноста на персоналните компјутери и софтверот како и на печатарските техники во последните дваесет години воведоа суштинска промена во издавањето на научните публикации. Дополнително, во последната деценија интернетот до толку го револуционеризира издаваштвото што доведе до менување на основната парадигма на печатените списанија. Macedonian Journal of Chemistry and Chemical Engineering во својата 40-годишна историја ги усвојуваше и се приспособуваше на овие трансформации. Со цел да се усвојат неминовните измени, како главен и одговорен уредник сметав за должност дека е неопходно да се воведе електронско уредување на списанието. Изборот беше меѓу комерцијални платформи и софтвер со отворен код, но поради ограниченото финансирање на списанието се одлучивме на софтвер со отворен код. Беше избран Open Journal Systems поради можноста за електронско поднесу: $\quad$ вање трудови и уредување, флексибилната кон- фигурација - во согласност со потребите, секциите, процесот на рецензирање итн., можноста за сеопфатно индексирање, алатките за читање, известувања и забелешки по е-пошта, опцијата за апстракти од докторски дисертации и заради локалното инсталирање. Меѓутоа, поради ограничената поддршка за поставување и водење, бара извесно познавање на компјутерски вештини. Општо земено, Open Journal Systems е одлична електронска уредувачка платформа и прикладно решение за списанија со низок буџет или за списанија што не сакаат да трошат многу на комерцијалните алтерантиви или едноставно ја поддржуваат идејата на софтвер со отворен код.

лучни зборови: софтвер со отворен пристап, отворени системи за списанија, електронско управување на уредувањето. 